\title{
Identification of Corynebacterium diphtheriae by immunofluorescence during a diphtheria epidemic
}

\author{
A. W. MCCRACKEN AND C. U. MAUNEY \\ From the Division of Microbial Pathology, Department of Pathology, The University of Texas Medical School \\ at San Antonio, USA
}

SYNOPSIS During a large epidemic of diphtheria, the technique of immunofluorescence was applied to specimens obtained from 310 patients, 77 of whom were diagnosed clinically as having the disease. The technique made use of commerical fluorescent antisera prepared against the somatic antigens of Corynebacterium diphtheriae. The results obtained by immunofluorescence of slides prepared directly from swabs were found to be unsatisfactory but when the swabs were subjected to prior incubation in a growth medium the results of immunofluorescence and bacterial culture agreed in $95 \%$ of specimens. Immunofluorescence applied to bacterial colonies obtained on primary isolation agreed completely with definitive bacterial identification. These two methods for the rapid identification of $C$. diphtheriae appeared to be as reliable as formal cultural and biochemical methods and could be usefully and economically applied to the examination of large numbers of clinical specimens during an epidemic.

Methods for the rapid identification of Corynebacterium diphtheriae by immunofluorescence have been available for some time; these methods have employed fluorescent antisera which react either with diphtheria toxin or with somatic antigens of the bacilli. Previous studies of these methods have made use of specially prepared antisera. Commercial fluorescent antisera are now available which have been prepared against somatic diphtherial antigens, but there have been few opportunities to evaluate these antisera during epidemics of the disease when they would seem to be most useful. During 1970 an epidemic of diphtheria occurred in San Antonio, Texas, in which 133 cases of the disease were confirmed by isolation of toxinogenic $C$. diphtheriae. During this outbreak the opportunity was taken to evaluate the technique of immunofluorescence of C. diphtheriae with commercial fluorescent antiserum by its comparison with standard bacteriological methods.

\section{Materials and Methods}

Duplicate slides were prepared for immunofluorescence in three ways: (1) directly from throat swabs; (2) from throat swabs which were first subjected to

Received for publication 26 November 1970. incubation for three to four hours in growth medium; (3) from bacterial colonies which, after overnight incubation on solid media had morphological features suggestive of $C$. diphtheriae.

The first two procedures were intended to provide rapid bacteriological identification to assist prompt clinical diagnosis; the third was aimed at more rapid definitive bacterial identification which is necessary both for clinical management of patients and initiation of public health measures.

Throat swabs were received from four groups of patients: (1) patients with a clinical diagnosis of diphtheria; (2) close contacts of cases of bacteriologically confirmed diphtheria; (3) patients with confirmed diphtheria after completion of treatment; (4) patients with pharyngitis who presented during the epidemic and in whom diphtheria had to be excluded bacteriologically.

\section{BACTERIOLOGICAL METHODS}

Duplicate swabs were placed in tubes containing $10 \mathrm{ml}$ of a modified Stuart's transport medium (Cary and Blair, 1964). We found that in this medium a light inoculum of $C$. diphtheriae would survive at least 24 days. Each swab for bacterial culture was inoculated on to $7.5 \%$ sheep blood agar, serum tellurite agar, and a Loeffler serum slant. The cultures were incubated overnight in a $\mathrm{CO}_{2}$-enriched atmos- 
phere. Colonies with appropriate morphological features were subcultured for urease production, nitrate reduction and demonstration of toxin production by the method of Elek (1949).

\section{IMMUNOFLUORESCENT METHODS}

Initially slides were prepared from swabs without prior incubation in a growth medium. This method was later abandoned in favour of incubation of swabs for three to four hours in $2 \mathrm{ml}$ brain-heart infusion broth containing $0.05 \%$ glucose. After incubation swabs were smeared within a circle, $1 \mathrm{~cm}$ in diameter etched on grease-free glass slides. For identification of bacterial isolates on solid media, slides were prepared by picking off suspicious colonies after overnight incubation and making a thin saline suspension on the slide. Slides were allowed to dry in the air and fixed in $95 \%$ ethanol for two to three minutes. Lyophilized fluorescent antiserum $^{1}$ to bacterial antigens of $C$. diphtheriae was reconstituted and absorbed with activated charcoal to decrease non-specific fluorescence. The antiserum was titrated against a stock strain of $C$. diphtheriae intermedius to determine the highest dilution which gave maximum $(4+)$ fluorescence. In this investigation this dilution was $1 / 10$; negative control antiserum ${ }^{1}$ (rabbit globulin conjugated with fluorescein isothiocyanate) was used at the same dilution. Positive control slides were prepared from brainheart infusion broth lightly inoculated with the stock strain. After fixation the slides were covered with 2 drops of $1 / 10$ fluorescent antiserum or $1 / 10$ negative control serum, incubated in a moist chamber for 20 minutes at $37^{\circ} \mathrm{C}$, washed in two changes of phosphate-buffered saline at $p \mathrm{H} \mathbf{7 \cdot 2}$ for 10 minutes, and a coverslip mounted in buffered glycerol was placed on each slide. The slides were examined within one hour of fluorescent staining by a Reichert Zetopan fluorescence microscope using dark ground illumin-

${ }^{1}$ Difco Laboratories, Detroit, Michigan, USA. ation. After scanning at a magnification of $\times 600$ for bright fluorescence, bacterial morphology and fluorescence were confirmed by examination under $\bar{G}$ oil immersion at a magnification of $\times 1,500$. To obviate observer bias, bacteriological and fluorescence methods were carried out in separate laboratories and the results reported independently.

The results of fluorescence were recorded as follows:

Negative: no fluorescence or fluorescence of $\vec{\circ}$ organisms morphologically distinct from $C \cdot \overrightarrow{\vec{\omega}}$ diphtheriae

Doubtful: soft (less than 2+) fluorescence of $\frac{2}{0}$ organisms resembling $C$. diphtheriae

Positive: bright $(2$ to $4+$ ) fluorescence of $\triangle$ organisms resembling $C$. diphtheriae

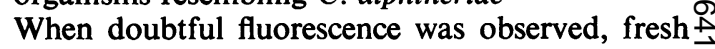
slides were prepared from the infusion broth tubes 0 and the test was repeated. Slides which were now? negative or remained doubtful were reported as being negative.

\section{Results}

The results obtained when slides were prepared directly from swabs without prior incubation are shown in Table I. Because of poor correlation between the results of this method and bacterial culture, this technique was discontinued. The results of bacterial culture and immunofluorescence preceded $\frac{\circ}{\circ}$

\begin{tabular}{|c|c|c|c|c|c|}
\hline $\begin{array}{l}\text { Patient } \\
\text { Group }\end{array}$ & $\begin{array}{l}\text { Positive } \\
\text { Fluor- } \\
\text { escence } \\
\text { Positive } \\
\text { Culture }\end{array}$ & $\begin{array}{l}\text { Negative } \\
\text { Fluor- } \\
\text { escence } \\
\text { Negative } \\
\text { Culture }\end{array}$ & $\begin{array}{l}\text { Negative } \\
\text { Fluor- } \\
\text { escence } \\
\text { Positive } \\
\text { Culture }\end{array}$ & $\begin{array}{l}\text { Positive } \\
\text { Fluor- } \\
\text { escence } \\
\text { Negative } \\
\text { Culture }\end{array}$ & Total \\
\hline $\begin{array}{l}\text { Clinical } \\
\text { diphtheria }\end{array}$ & $3(18 \%)$ & 0 & $13(82 \%)$ & 0 & $16(100 \%)$ \\
\hline
\end{tabular}

Table I Comparison of results of bacterial culture and immunofluorescence without prior incubation of swabs

\begin{tabular}{|c|c|c|c|c|c|c|}
\hline Group No. & Diagnosis & $\begin{array}{l}\text { Positive } \\
\text { Fluorescence } \\
\text { Positive Culture }\end{array}$ & $\begin{array}{l}\text { Negative } \\
\text { Fluorescence } \\
\text { Negative Culture }\end{array}$ & $\begin{array}{l}\text { Negative } \\
\text { Fluorescence } \\
\text { Positive Culture }\end{array}$ & $\begin{array}{l}\text { Positive } \\
\text { Fluorescence } \\
\text { Negative Culture }\end{array}$ & Totals \\
\hline 1 & Clinical diphtheria & $53(68.8 \%)$ & $12(15.6 \%)$ & $8^{1}(10.4 \%)$ & $4(5 \cdot 2 \%)$ & $77(100 \%)$ \\
\hline 2 & $\begin{array}{l}\text { Diphtheria } \\
\text { contacts }\end{array}$ & $1(0.8 \%)$ & $114(98.4 \%)$ & 0 & $1(0.8 \%)$ & $116(100 \%)$ \\
\hline 3 & $\begin{array}{l}\text { Treated diphtheria } \\
\text { cases }\end{array}$ & $1(2 \cdot 2 \%)$ & $45(97.8 \%)$ & 0 & 0 & $46(100 \%)$ \\
\hline \multirow[t]{2}{*}{4} & Pharyngitis & 0 & $71(100 \%)$ & 0 & 0 & $71(100 \%)$ \\
\hline & Totals & $55(17 \cdot 7 \%)$ & $242(78 \%)$ & $8^{1}(2.6 \%)$ & $5(1 \cdot 7 \%)$ & $310(100 \%)$ \\
\hline
\end{tabular}

Table II Comparison of results of bacterial culture and immunofluorescence following incubation of swabs

IIncludes one non-toxinogenic strain 
by incubation of the swabs on 310 patients are shown in Table II. In patient group 1 there was $80 \%$ agreement between clinical diagnosis and bacterial culture and $74 \%$ agreement between clinical diagnosis and immunofluorescence. In group 1 the results of immunofluorescence and culture agreed in $84.4 \%$ of specimens and overall there was $95 \%$ agreement between the two methods in the 310 samples tested. There were eight instances in which $C$. diphtheriae was detected by culture alone; four specimens were positive by immunofluorescence alone. One nonstrain was detected by both methods.

Seventy-two bacterial colonies which morphologically resembled $C$. diphtheriae on solid media were subjected to immunofluorescent, biochemical, and toxinogenic tests. There was $100 \%$ agreement between the results of definitive bacterial identification and immunofluorescence; 66 colonies were positive and six negative by both methods.

\section{Discussion}

Two methods of immunofluorescence have been applied to the rapid diagnosis of infections due to $C$. diphtheriae. The first of these makes use of a fluorescent antibody prepared against diphtheria toxin (Jones and Moody, 1960; Whitaker, Nelson, and Fink, 1961). This method has the theoretical advantage of making a distinction between toxinogenic and non-toxinogenic strains of the organism. Whitaker et al (1961) thought that this method was useful and highly specific but Allen and Cluff (1963) found it to be a non-specific procedure because of fluorescence of other bacteria especially diphtheroids. They also noted that toxinogenic and non-toxinogenic strains showed fluorescence. This failure to distinguish between the two strains was probably due to other antibodies to $C$. diphtheriae present in the antitoxin. The method of Moody and Jones (1963) in which fluorescent antibody is prepared against $\mathrm{O}$ and $\mathrm{K}$ bacterial somatic antigens of $C$. diphtheriae appears to be a more specific and satisfactory method, although it does not detect nontoxinogenic strains. The commercial antiserum used in this investigation was prepared by this method.

It would be of great value in the clinical management of patients suspected of having diphtheria if rapid and reliable identification of the infecting organism could be obtained by the fluorescent antibody technique on slides prepared directly from throat swabs. However, since $82 \%$ of specimens from patients with clinical diphtheria showed negative fluorescence by this method but positive bacterial culture, the technique appears to be of no value. Ghag and Sant (1966) applied specially prepared fluorescent antiserum to slides prepared directly from throat swabs and found 33 instances $(74 \%)$ of negative fluorescence out of 41 specimens which were positive for $C$. diphtheriae by culture.

The results of immunofluorescence and bacterial culture showed $95.1 \%$ agreement in the 310 specimens examined (Table II). Although the measure of agreement was less $(84.4 \%)$ in group 1 alone this may simply reflect a sampling error in obtaining duplicate swabs or the length of time the swabs were incubated before applying the fluorescent antibody technique. Ghag and Sant (1966), who studied endemic diphtheria in Bombay, India, and reported a $92 \%$ correlation between immunofluorescence after four hours' incubation and bacterial culture, also found that by increasing the incubation time of the swabs to $12-18$ hours there was $100 \%$ agreement between the two methods. However, this prolonged incubation time detracts from the value of the method as a rapid diagnostic technique. The occurrence of a number of instances in which positive results were obtained by one method only suggests that both culture methods and immunofluorescence might by used simultaneously to advantage in the laboratory diagnosis of diphtheria.

During an epidemic of diphtheria large numbers of patients who belong to groups 2 and 4 (Table II) may have to be screened for infection by $C$. diphtheriae and appropriate public health measures taken on the basis of laboratory findings. In this situation the use of immunofluorescence seems to offer a rapid reliable and economic method of examining swabs from such patients. Results with fluorescent antibody which correlate in more than $90 \%$ of specimens with bacterial culture could be expected; this correlation could be even further improved by prolonging the incubation time of the swabs beyond four bours, which in this group of patients would not be a serious disadvantage.

The recognition of $C$. diphtheriae by fluorescence microscopy from morphology and arrangement of the bacilli presented little difficulty. There was no relationship between the degree of fluorescence and the strain of $C$. diphtheriae although examples of gravis, intermedius, and mitis strains were included in the bacterial isolates obtained throughout the epidemic. No fluorescence was observed in any organisms that could be confused with $C$. diphtheriae. Diphtheroid organisms were frequently found on culture of specimens which were negative by immunofluorescence and no diphtheroids were noted on culture of those five specimens which were positive by fluorescence alone. This suggests that diphtheroids did not fluoresce with the antisera used. Fluorescence of other micro-organisms was a fairly common, but minor problem; streptococci and Candida albicans often fluoresced brightly despite absorption of the 
antisera but these organisms were readily distinguished by their size and typical morphology.

Immunofluorescence applied to identification of bacterial colonies showed complete agreement with the results of biochemical methods. This method would appear to be as reliable as and more rapid and economical than fermentation and other biochemical reactions for diagnosis of bacterial species, although inapplicable to the recognition of toxinogenic strains.

The authors wish to thank Miss Violet Armour MSc and the technicians of Bexar County Hospital Bacteriology Laboratories for their assistance.
References

Allen, J. C., and Cluff, L. E. (1963). Identification of toxinogenic C. 은 diphtheriae with fluorescent antitoxin: demonstration of non- $\rightrightarrows$ specificity. Proc. Soc. exp. Biol. (N.Y.), 112, 194-199.

Cary, S. G., and Blair, E. B. (1964). New transport medium for shipment of clinical specimens. J. Bact., 88, 96-98.

Elek, S. D. (1949). The plate virulence test for diphtheria. J. clin. Path., 2, 250-258.

Ghag, N. K., and Sant, M. V. (1966). Rapid laboratory diagnosis of $\frac{\bar{\sigma}}{\vec{T}}$ diphtheria by fluorescent antibody technique. Ind. J. med. Sci., ه 20, 914-919.

Jones, W. L., and Moody, M. D. (1960). Staining toxigenic Coryne- $\stackrel{\curvearrowright}{\sim}$ bacterium diphtheriae with fluorescent antitoxin. Bact. Proc., $\vec{\overrightarrow{ }}$ 141.

Moody, M. D., and Jones W. L. (1963). Identification of Corynebacterium diphtheriae with fluorescent antibacterial reagents $\vec{\omega}$ J. Bact., 86, 285-293.

Whitaker, J. A., Nelson, J. D., and Fink, C. W. (1961). The fluorescent antitoxin test for immedia te diagnosis of diphtheria. Pediatrics, $\bigcirc$ 27, 214-218.

\section{Reports and Bulletins prepared by the Association of Clinical Biochemists}

The following reports and bulletins are published by the Association of Clinical Biochemists. They may be obtained $\frac{0}{\circ}$ from The Administrative Office, Association of Clinical Biochemists, 7 Warwick Court, Holborn, London, WC1R 5DP. ำ The prices include postage, but airmail will be charged extra. Overseas readers should remit by British Postal or Money $\vec{\oplus}$ Order. If this is not possible the equivalent of 50p is the minimum amount that can be accepted.

SCIENTIFIC REPORTS

3 Automatic Dispensing Pipettes. An assessment of 35 commercial instruments 1967 P. M. G. BROUGHTON, A. H. GOWENLOCK, G. M. WIDDOWSON, and K. A. AHLQUIST $85 p(\$ 2)$

4 An Evaluation of five Commercial Flame Photometers suitable for the Simultaneous Determination of Sodium and Potassium March 1970 P. M. G. BROUGHTON and J. B. DAWSON $85 p(\$ 2)$

SCIENTIFIC REVIEWS

1 The Assessment of Thyroid Function March 1971 F. V. FLYNN and J. R. HOBBS $62 \frac{1}{2} p(\$ 1.50)$

\section{TECHNICAL BULLETINS}

9 Determination of Urea by AutoAnalyzer November

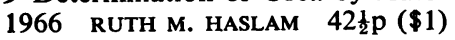

11 Determination of Serum Albumin by AutoAnalyzer using Bromocresol Green October 1967 B. E. NORTHAM and G. M. WIDDOwsON $42 \frac{1}{2} \mathrm{p}(\$ 1)$

13 An Assessment of the Technicon Type II Sampler Unit March 1968 B. C. GRAY AND G. K. MCGOWAN $42 \frac{1}{2} \mathrm{p}(\$ 1)$

14 Atomic Absorption Spectroscopy. An outline of its principles and a guide to the selection of instruments May 1968 J. B. DAWSON and P. M. G. BROLGHTON $42 \frac{1}{2} p(\$ 1)$
15 A Guide to Automatic Pipettes (2nd edition) June 1968 P. M. G. BROUGHTON $42 \frac{1}{2} \mathrm{p}(\$ 1)$

16 A Guide to Automation in Clinical Chemistry May $\stackrel{\circ}{\mathbb{Q}}$ 1969 P. M. G. BROUGHTON 621 $\frac{1}{2}(\$ 1.50)$

17 Flame Photometers (2nd edition) 1969 P. WILDING $62 \frac{1}{2} \mathrm{p}(\$ 1.50)$

18 Control Solutions for Clinical Biochemistry (4th edition) March 1970 P. M. G. BROUGHTON 62t $\frac{1}{2}$ O $(\$ 1.50)$

19 Spectrophotometers. A comparative list of low-priced instruments readily available in Britain May $1970 \frac{3}{3}$ C. E. WILDE and P. SEWELL $62 \frac{1}{2} p(\$ 1.50)$

20 Quantities and Units in Clinical Biochemistry June $>$ 1970 P. M. G. BROUGHTON $62 \frac{1}{2} \mathrm{p}(\$ 1.50)$ More than 30 copies in units of 10 at $20 \mathrm{p}$

21 Filter Fluorimeters: A comparative list of 18 instruments September 1970 H. BRAUNSBERG and s. S. N BROWN $62 \frac{1}{2} \mathrm{p}(\$ 1.50)$

22 Bilirubin standards and the Determination of Bilirubip by Manual and Technicon AutoAnalyzer Methods. January 1971 BARBARA BILLING, RUTH HASLAM ande N. WALD $62 \frac{1}{2} \mathrm{p}(\$ 1.50)$

23 Interchangeable Cells for Spectrophotometers and Fluorimeters September 1971 E. S. BROWN and A. H, GOWENLOCK $62 \frac{1}{2} \mathrm{p}(\$ 1.50)$ 